\title{
DETEKSI 4 TANDA VITAL PASIEN RUMAH SAKIT BERBASIS FUZZY DATABASE
}

\author{
A Haris Rangkuti \\ Computer Science Department, School of Computer Science, Binus University \\ Jl. KH. Syahdan No. 9, Kebon Jeruk, Jakarta Barat 11480 \\ rangku2000@binus.ac.id
}

\begin{abstract}
To assist the performance of medical technicians in nursing patients effectively and efficiently, information technology appears as a dominant support. Utilizing information technology, patient's diagnoses can be reported to a doctor as soon as possible, as well as the patient's condition which needs to be monitored regularly. It is necessary to build a monitoring information system of hospital that is able to present timely information regarding the patient's condition characterized by four vital signs which are temperature, blood pressure, pulse, and respiration. For the four vital signs monitoring, fuzzy logic concept is implemented. If vital signs approach 1, the patient is close to recovery. Conversely, if the signs are 0, the patient still needs medical treatment. This system also helps nurses in order to provide answers to the families of patients who want to know the development of the patient's condition, as well as the recovery based on the average percentage of Fuzzy max of four vital signs. By Fuzzy-based monitoring system, monitoring the patient's condition becomes simpler and easier.
\end{abstract}

Keywords: patient monitoring, fuzzy, fuzzy max, vital signs

\begin{abstract}
ABSTRAK
Untuk membantu kinerja petugas rumah sakit dalam melayani pasien secara efektif dan efisien, peranan teknologi informasi menjadi pendukung yang dominan. Dengan memanfaatkan teknologi informasi, keluhan penyakit yang dirasakan pasien dapat dilaporkan secepat mungkin kepada dokter, termasuk kondisi pasien yang perlu dipantau secara berkala. Untuk itu diperlukan sistem informasi monitoring rumah sakit yang mampu menyajikan informasi secara cepat mengenai kondisi pasien yang ditandai dengan empat tanda vital yaitu suhu, tekanan darah, denyut nadi, dan pernapasan. Untuk monitoring terhadap empat tanda vital, digunakan konsep logika fuzzy. Jika tanda vital mendekati diantara angka 1, pasien rawat sudah mendekati kesembuhan. Sebaliknya, jika mendekati angka 0, kondisi pasien masih bermasalah. Sistem ini juga membantu perawat dalam rangka memberikan jawaban kepada keluarga pasien jika ingin mengetahui pengembangan kondisi pasien, termasuk persentase kesembuhan berdasarkan rata rata dari Fuzzy max dari empat tanda vital. Dengan sistem monitoring berbasis Fuzzy, monitoring kondisi pasien menjadi lebih sederhana dan mudah.
\end{abstract}

Kata kunci: monitoring pasien, fuzzy, fuzzy max, tanda vital 


\section{PENDAHULUAN}

Rumah sakit sebagai salah satu tempat yang melayanani masyarakat, memiliki pekerjaan dan kegiatan yang menuntut profesionalitas dan kemudahan dalam pelayanan kepada pasien. Pelayanan yang dilakukan di rumah sakit terdiri dari: pertolongan pertama pada kecelakaan, perawatan, operasi, penyembuhan, maupun layanan konsultasi kesehatan. Karena setiap pasien yang datang memiliki kasus yang berbeda, maka penanganan dan prosedur yang dilaksanakan dalam setiap pelayanan dan tindakan pengobatan juga berbeda sesuai kondisi pasien. Kondisi pasien dapat dinilai dari beberapa faktor yaitu: umur, jenis kelamin, penyakit, tanda vital (suhu, tekanan darah, denyut nadi, dan pernapasan), riwayat kesehatan dan faktor-faktor lainnya.

Untuk membantu kinerja petugas rumah sakit dalam melayani pasien dengan efektif dan efisien, maka teknologi informasi juga digunakan di rumah sakit. Contoh penggunaan teknologi informasi di rumah sakit adalah pada sistem pendaftaran, rekam medis pasien, informasi mengenai jadwal dokter dan fasilitas rumah sakit yang dapat diakses lewat internet. Hal ini menunjukkan bahwa pemakaian teknologi informasi dianggap umum karena setiap unit usaha dengan bantuan teknologi informasi dapat mengelola data mengenai aktivitas usahanya secara efektif dan efisien, yang nantinya dapat menghasilkan informasi yang menjadi dasar pengambilan keputusan guna peningkatan pelayanan pada rumah sakit yang pada akhirnya akan memuda

Padahal, kondisi dari pasien perlu untuk dipantau secara berkala dan hasil dari pemantauan dan keluhan penyakit yang dirasakan pasien perlu untuk dilaporkan secepat mungkin kepada dokter. Sistem monitoring yang dilakukan pada rumah sakit secara umum, kurang mampu membantu menyajikan informasi secara cepat menenai informasi kondisi pasien yang perlu disampaikan kepada dokter supaya dapat cepat ditangani. Solusi yang diusulkan untuk mengatasi masalah yang ada pada rumah sakit adalah teknologi informasi monitoring pasien dengan menggunakan media intranet dan internet. Dengan teknologi informasi tersebut, informasi mengenai kondisi pasien dapat disampaikan kepada dokter dan keluarga pasien dengan cepat, tepat dan aman.

Tujuan penelitian ini adalah untuk: (1) mempermudah perawat dalam melakukan monitoring kondisi pasien rawat inap berdasarkan empat tanda vital (suhu, tekanan darah, denyut nadi, dan pernapasan); (2) mempermudah dalam pengolahan informasi kondisi seluruh pasien dengan empat tanda vital; (3) mempercepat penyampaian data monitoring pasien kepada dokter, yang sedang tidak ada di tempat atau kepada keluarga pasien; (4) menghasilkan sistem monitoring pasien yang akurat, tepat dan cepat; (5) sebagai bahan referensi penelitian selanjutnya.

Ruang lingkup penelitian ini adalah sebagai berikut: (1) pelitian tidak memfokuskan pada informasi mengenai identitas pasien, pengunjung, dan petugas rumah sakit. Penelitian difokuskan pada kondisi pasien rawat inap; (2) penelitian berdasarkan pada empat tanda vital pasien rawat inap yaitu suhu, tekanan darah, denyut nadi, dan pernapasan; (3) penelitian ini dikembangkan dengan mengunakan konsep fuzzy database.

\section{METODE}

Dalam melakukan penelitian terhadap deteksi pasien rawat inap dengan empat tanda vital , digunakan metode pengembangan sistem informasi yang umum dengan beberapa tahapan, yaitu: (1) pengumpulan data (kondisi pasien); (2) analisis kebutuhan pasien yang meliputi: kebutuhan variabel pendukung, fungsi anggota setiap variabel, serta input dan output; (3) perancangan aplikasi fuzzy 
database yang meliputi perancangan input fuzzy query, perancangan output query, dan prototipe aplikasi fuzzy database.

\section{Fuzzy Set}

Definisi Fuzzy set Menurut Stuart Russell dan Peter Norvig (2003) adalah suatu kondisi yang menyatakan seberapa baik suatu objek puas atas jawaban yang tidak jelas/masih samar-samar. Himpunan pada fuzzy berbeda dengan himpunan yang biasa/klasik. Himpunan klasik memiliki batas yang jelas mengenai keanggotaan dari tiap elemen pada masing-masing himpunannya. Contohnya: himpunan tingkat kesehatan pasien pada suatu rumah sakit, makanan yang habis dan masih utuh merupakan bagian dari himpunan tingkat kesehatan pasien, dimana makanan yang habis dianalogikan sebagai kondisi 1 dan makanan yang masih utuh dianalogikan sebagai 0 .

Bagaimana jika pasien hanya memakan sebagian dari makanannya dan tidak dihabiskan sehingga masih bersisa? Hal ini membuat kondisi tersebut perlu dibuatkan suatu wilayah baru yang dapat menampung kondisi tersebut sehingga hasil yang didapat bias diolah. Dari analogi tersebut dapat memberi gambaran mengenai fuzzy set. Fuzzy set merupakan dasar yang penting bagi Fuzzy logic, karena Fuzzy set bukanlah metode yang menyatakan semua bernilai pasti melainkan metode yang mampu mengolah kondisi yang terjadi untuk dapat digunakan untuk analisis. Pernyataan yang samarsamar itulah yang membuatnya disebut fuzzy.

Secara umum, kesimpulan tentang himpunan dan fungsi keanggotaan fuzzy dinyatakan sebagai berikut: (1) fuzzy set menekankan kosep variabel samar-samar(vague or fuzzy variable) seperti variabel kondisi pasien, temperatur, dll.; (2) fuzzy set mengijinkan keanggotaan parsial dari suatu himpunan seperti makanan yang tidak habis dinyatakan sebagai kondisi yang mendekati habis namun dengan tingkat di bawah 1; (3) tingkat keanggotaan fuzzy dalam fuzzy set berada di antara 0 sampai 1; (4) tiap fungsi keanggotaan $\mu$ berasosiasi dengan sebuah fuzzy set tertentu dan memetakan suatu nilai input ke nilai derajat keanggotaan yang sesuai; (5) semua data pasien akan disimpan ke dalam bentuk database baik yang berupa data hasil diagnosa maupun hasil kesimpulan yang merupakan hasil pengolahan dari sistem (fuzzy database).

Contohnya: dalam kasus fuzzy set suhu panas mempunyai fungsi keanggotaan sendiri, yaitu $\mu$ panas, yang berbeda dengan fungsi keanggotaan dari fuzzy set suhu dingin, yaitu $\mu$ dingin. Data yang diambil langsung dari kondisi pasien hanya akan dibaca oleh dokter. Data hasil dari pengolahan sistem fuzzy akan diinformasikan kepada keluarga pasien. Ini dilakukan untuk menghindari kesalahpahaman antar keluarga dengan pihak rumah sakit, sebagai penyebab kenapa pasien masih perlu dirawat. Untuk proses dapat dilihat pada Gambar 1 di bawah ini:

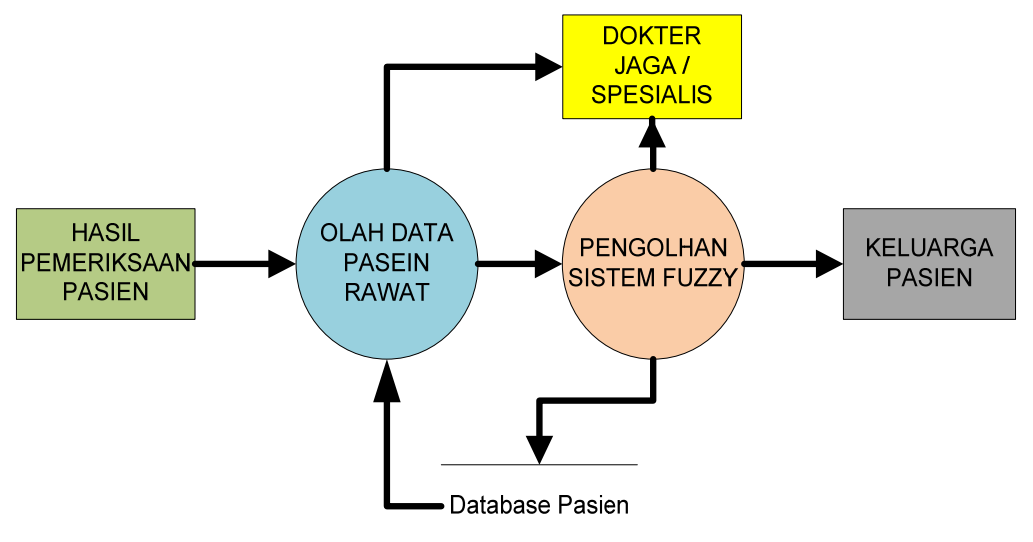

Gambar 1 Tahapan Penyebaran informasi pasien rawat Inap kepada dokter dan keluarga pasien 


\section{Fuzzy Logic (Logika Fuzzy)}

Menurut Stuart Russell dan Peter Norvig (2003), Fuzzy logic sendiri berarti metode untuk penalaran dengan ekspresi logis yang menggambarkan keanggotaan dalam fuzzy set.

Logika Fuzzy memungkinkan nilai keanggotaan antara 0 dan 1, tingkat keabuan dan juga hitam dan putih, dan dalam bentuk linguistik, konsep tidak pasti seperti "sedikit", "lumayan", dan "sangat". Logika ini berhubungan dengan set fuzzy dan teori kemungkinan. Logika fuzzy diperkenalkan oleh Dr. Lotfi Zadeh dari Universitas California, Berkeley pada 1965.

\section{Fuzzy Control}

Fuzzy control adalah metodologi untuk membangun sistem kontrol di mana pemetaan antara bernilai real input dan output parameter diwakili oleh aturan fuzzy. Fuzzy control dianggap berhasil karena mempunyai basis aturan kecil, dan parameter yang dapat disesuaikan untuk peningkatan kinerja sistem. (Stuart Russell dan Peter Norvig, 2003, p527) . Secara umum gambaran pengunaan empat tanda vital terhadap fuzzy logic dan control dapat dilihat pada Gambar 2.

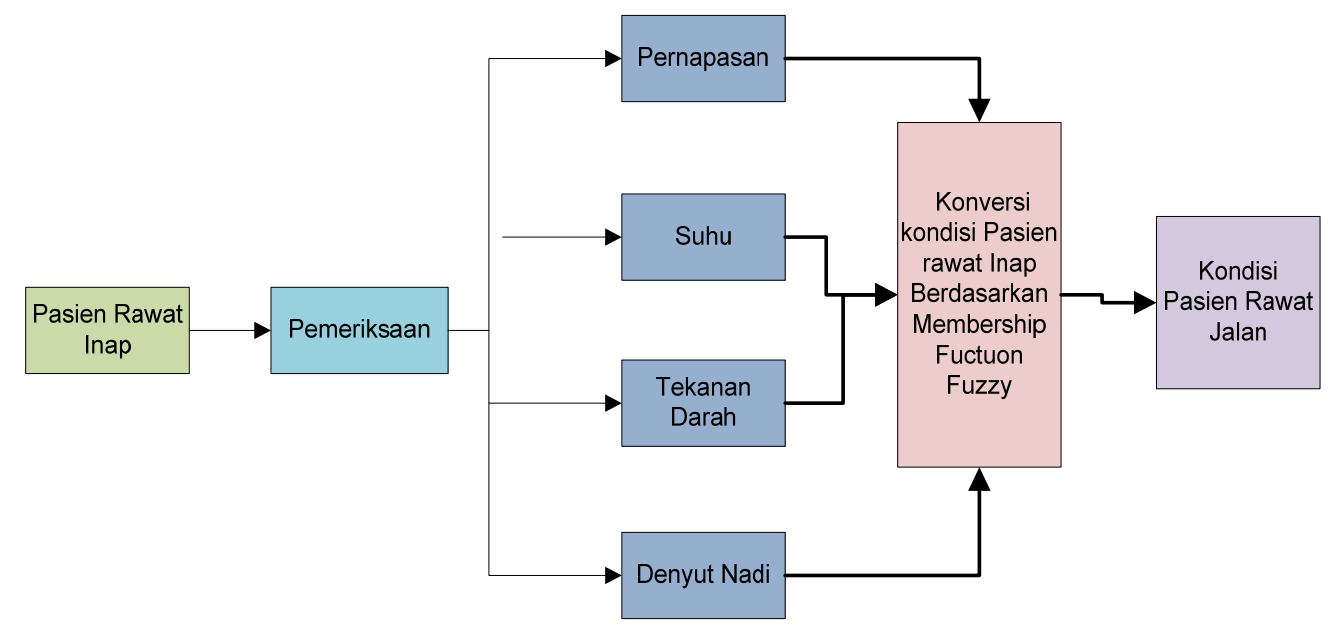

Gambar 2 Deteksi pasien berdasarkan 4 tanda vital dengan fuzzy logic dan control

\section{HASIL DAN PEMBAHASAN}

\section{Solusi terhadap Permasalahan}

Secara umum permasalahan yang dihadapi dalam melakukan monitoring pasien rawat inap adalah: (1) kesulitan dalam mengisi formulir kondisi pasien karena tidak ada pemahaman yang jelas terhadap variabel utama melihat kondisi pasien; (2) terdapat kemungkinan kesalahan perhitungan dalam melakukan monitoring pasien; (3) laporan tidak langsung dikirim ke dokter sehingga terjadi delay time karena menunggu doctor visit; (4) hilangnya atau rusaknya sejumlah dokumen penting karena hanya tersimpan dalam bentuk cetak.

Dengan menganalisis permasalahan yang dihadapi solusi yang dilakukan dalam penelitian ini adalah merancang konsep fuzzy logic yang terintegrasi dalam Sistem untuk mempermudah monitoring pasien oleh dokter maupun perawat. Konsep fuzzy logic ini melihat dari empat faktor umum yang biasa 
dilakukan oleh perawat maupun dokter saat pasien masuk pertama kali, yaitu: suhu, tekanan darah, denyut nadi, pernafasan.

Dengan adanya empat faktor yang menggunakan konsep fuzzy logic ini adengan cara mengitung rata-rata dari empat faktor tersebut. Setelah itu mendapatkan nilai antara 0-1 yang terdiri dari:

mendekati angka $0=$ keadaan pasien yang masih sakit, dan

mendekati angka 1 = keadaan pasien yang sudah membaik atau keadaan sehat.

Konsep ini dapat membantu perawat dan dokter menilai keadaan pasien tersebut. Untuk penelitian ini gambaran pasien yang akan dilakukan penelitian berdasarkan umur adalah sebagai berikut:

Variabel umur dibagi menjadi 4 kategori: (1) bayi umur $<5$ tahun; (2) anak-anak $5 \leq$ umur $<$ 15 tahun; (3) dewasa $15 \leq$ umur $<55$ tahun; (4) orang tua umur $\geq 55$ tahun.

Pengukuran terhadaP tanda-tanda vital memiliki empat variabel, tiap variabel direpesentasikan dengan menggunakan persentase. Setiap persentase mewakili artinya masing-masing. Berikut ini adalah keterangan dari persentase dalam mengukur kondisi pasien yang digunakan:

\begin{tabular}{|c|c|c|}
\hline$\leq 20 \%$ & \multicolumn{2}{|c|}{ Sangat Kritis } \\
\hline$<20 \leq 40 \%$ & $=$ & Kritis \\
\hline$<40 \leq 60 \%$ & $=$ & Sakit \\
\hline$<60 \leq 80 \%$ & $=$ & Sehat \\
\hline$<81 \leq 100 \%$ & $=$ & Sangat Sehat \\
\hline
\end{tabular}

Secara umum tahapan proses pemeriksaan pasien rawat jalan yang dilakukan dalam mengembangkan sistem monitoring Pasien rawat jalan berbasis fuzzy database dengan bantuan teknologi informasi adalah sebagai berikut (Gambar 3):

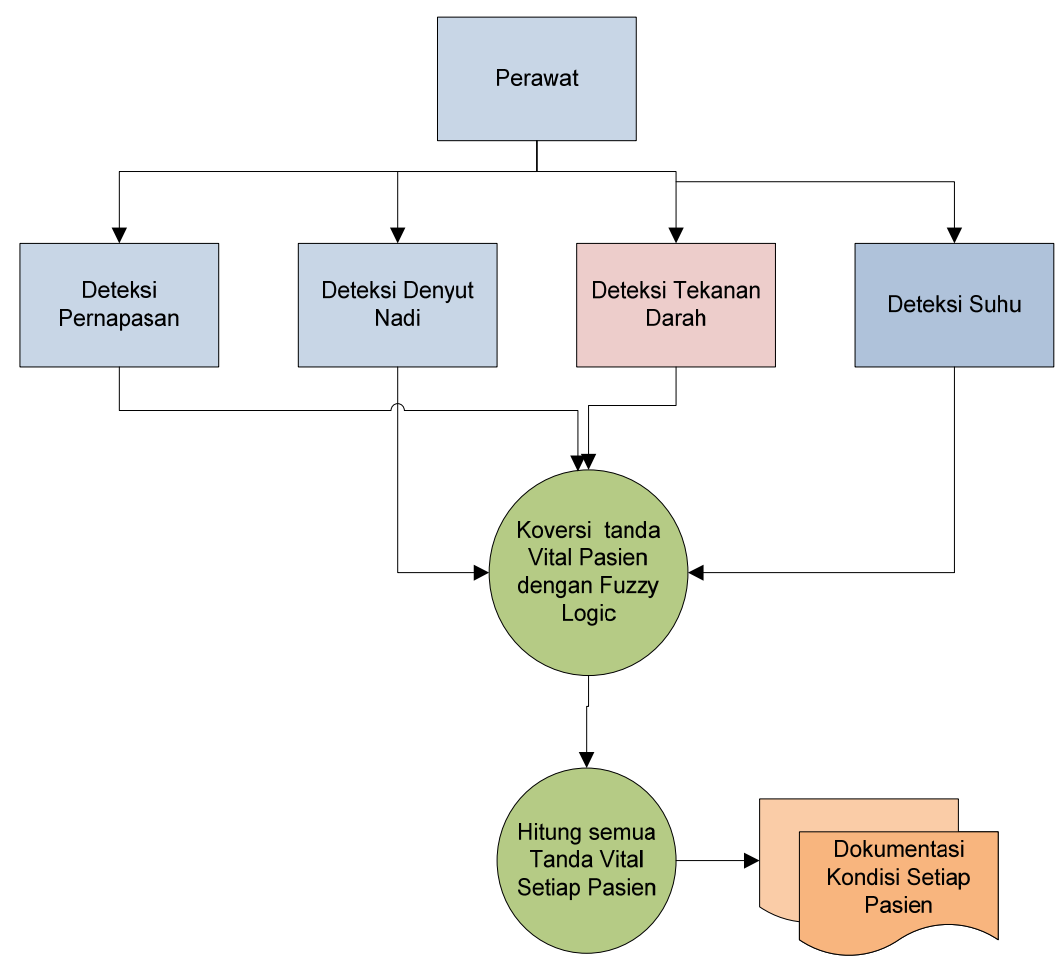

Gambar 3 Tahapan monitoring pasien berbasis fuzzy control (database) 
Dari Gambar 3 terlihat tahapan proses menghitung kondisi pasien, dimulai dengan mengumpulkan hasil deteksi pasien berdasarkan empat tanda vital. selanjutnya hasil deteksi akan dikonversi ke dalam bilangan hitungan fuzzy logic. Secara lebih lengkap tahapan dalam menganalisis kondisi pasien berdasarkan empat tanda vital adalah sebagai berikut:

\section{Tahapan Monitoring Pasien Berbasis Fuzzy Kontrol}

Untuk melakukan penelitan terhadap seleksi citra dalam pencarian citra berbasis ciri di database, ada lima tahap yang akan dilakukan yaitu: (1) persiapan (pengumpulan data pasien empat tanda vital) oleh perawat; (2) konversi hasil pengumpulan empat tanda vital ke dalam bilangan fuzzy logic; (3) menghitung kondisi pasien secara keseluruhan; (4) dokumentasi hasil perhitungan empat tanda vital per pasien; (5) pembuatan prototipe sistem monitoring pasien.

Persentase di atas mewakili semua variabel, yaitu variabel suhu, Tekanan darah, denyut nadi dan pernapasan.

\section{Tahap Persiapan/ Pengumpulan Data}

Dalam pengumpulan data pasien terhadap empat tanda vital (pernapasan, tekanan darah, suhu dan denyut nadi) dilakukan secara hati-hati dan bertahap. Termasuk juga dalam melakukan pengambilan data harus dilakukan lebih dari satu kali. Ini dilakukan untuk memastikan bahwa semua data yang diambil pada setiap pasien terhadap empat tanda vital sudah benar dan akurat.

\section{Tahapan Konversi Hasil Pengumpulan Data Pasien}

Setelah semua data empat tanda vital untuk pasien sudah dilakukan, tahap selanjutnya adalah melakukan konversi terhadap semua data yang sudah dikumpulkan oleh perawat ke dalam bentuk fuzzy logic. Sehingga dengan konversi tersebut dapat diketahui kondisi pasien sesegera mungkin sebagai contoh:

Suhu pasien adalah $36,8 \mathrm{C}$

$\mu 100 \%[36,8]=(36,8-36) /(37-36)$

$$
=0,8 / 1=0,8
$$

Berdasarkan input suhu yang dimasukkan, yaitu $36,8^{\circ}$, persentase terendah yang terletak di sebelah kiri $36,8^{\circ}$ adalah $80 \%$, sedangkan persentase tetinggi yang terletak di kanan $36,8^{\circ}$ adalah $100 \%$.

Maka kondisi $=$ persentase terendah $+\left[\right.$ derajat keanggotaan $(\mu[\mathrm{x}])^{*}($ persentase tertinggi-terendah $\left.)\right]$

$=80 \%+(\mu 100 \%[36,8] * 20 \%)$

$=0,8+(0,8 * 0.2)=0,96 / 96 \%$ (sangat sehat)

Jadi, suhunya dinyatakan sangat sehat.

Namun untuk denyut nadi 68.5 , maka

$$
\begin{aligned}
\mu 60 \%[68,5] & =(68,5-67,5) /(72,5-67,5)=1 / 5=0,2 \\
\text { Kondisi } & =40 \%+(\mu 60 \%[68,5] * 20 \%) \\
& =0,4+(0,2 * 0.2)=0,44 / 44 \% \text { (sakit) }
\end{aligned}
$$

\section{Tahapan Menghitung Kondisi Pasien Secara Keseluruhan}

Setelah dilakukan konversi nilai terhadap empat tanda vital pada setiap pasien menjadi prosentase bilangan fuzzy, secara keseluruhan perawat atau dokter dapat mengetahui dari kondisi dari empat tanda vital tersebut. Termasuk juga mengetahui tanda vital mana saja yang masih mempunyai masalah. Karena jika salah satu tanda vital ini mempunyai masalah, maka perawat/ dokter belum dapat memberikan izin pulang kepada pasien, kecuali atas permintaan pasien sendiri. Sebagai contoh: jika penggunaan sistem fuzzy pada pasien yang umurnya 21 tahun, suhu $36^{\circ} \mathrm{C}$, tekanan darah 
120/60mmHG, denyut nadi 77/menit, pernapasan 18/menit, kesimpulannya, kondisi suhu $=4$, kondisi tekanan darah $=5$, kondisi denyut nadi $=4$, kondisi pernapasan $=5$.

Dari data (kondisi suhu, kondisi tekanan darah, kondisi denyut nadi, kondisi pernapasan) akan digunakan nilai minimum untuk menyatakan kondisi pasien. Nilai minimum yang didapat $=4$, maka kondisi pasien $=$ sehat

\section{Tahapan Pengembangan Sistem Prototipe Monitoring Pasien Rawat Inap}

Setelah memastikan bahwa dalam setiap tahapan dalam memonitoring pasien rawat inap berbasis fuzzy kontrol sudah sesuai dengan kondisi pasien sebenarnya dan sekaligus mengikuti aturan fuzzy, tahap selanjutnya adalah pembuatan aplikasi prototipe sistem monitoring pasien. Diharapkan aplikasi monitoring tersebut akan memudahkan tugas perawat dalam memberikan pelayanan kepada pasien dan mempercepat pemberian informasi kepada dokter. Karena secara umum aplikasi monitoring pasien ini dikembangkan berbasis Internet, dokter dapat memotoring kondisi pasien dimana dan kapan saja. Keluarga pasien yang ingin mendapatkan informasi langsung dari perawat atau dokter jaga mengenai kondisi pasien harus datang ke rumah sakit. Secara umum tahapan monitoring pasien hingga ke dokter dapat dilihat pada Gambar 4 di bawah ini:

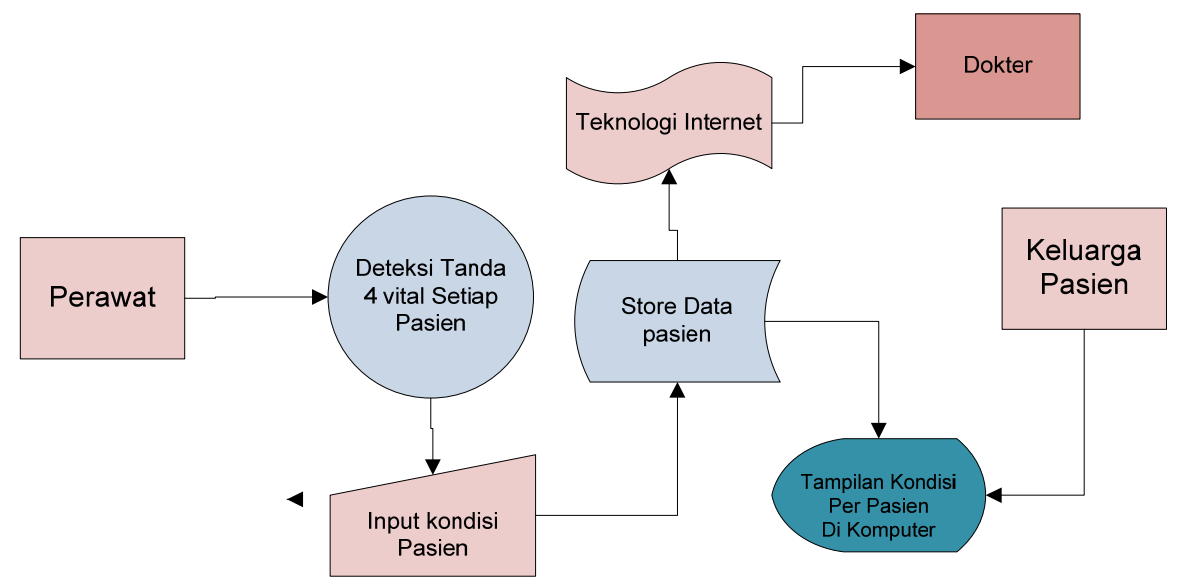

Gambar 4 Tahapan proses monitoring pasien oleh dokter dan keluarga pasien

\section{PENUTUP}

Berdasarkan hasil penelitian tentang kebutuhan sistem monitoring pasien berbasis fuzzy Control pada rumah sakit, dapat diambil kesimpulan sebagai berikut: (1) dalam melakukan deteksi empat tanda vital terhadap pasien rawat berbasis fuzzy database dilakukan dengan sistem monitoring pasien menjadi terkomputerisasi, sehingga mempermudah pengguna untuk mengaksesnya; (2) sistem monitoring pasien berbasis fuzzy control ini membantu rumah sakit khususnya dokter dan perawat untuk memantau dan memonitoring keadaan pasien. Khusus untuk dokter dapat mengetahui kondisi pasien dimana saja dan kapan saja melalui internet (web based); (3) dengan adanya sistem monitoring pasien ini, penyajian data-data kondisi pasien ditampilkan secara lebih lengkap sehingga memudahkan user untuk mendapatkan informasi kondisi pasien secara akurat; (4) sistem monitoring pasien berbasis fuzzy database ini membantu mengurangi terjadinya human error pada sistem kerja manual yang sebelumnya diterapkan rumah sakit. Sistem monitoring pasien ini memudahkan pencatatan keadaan pasien melalaui empat tanda vital (suhu, denyut nadi, pernafasan, tekanan darah); (5) mempermudah admin/ user rumah sakit terbantu dengan adanya sistem monitoring pasien ini dalam hal 
memperbaharui data dan informasi; (5) dengan adanya database pada sistem monitoring pasien, data menjadi lebih tersusun rapi.

Saran-saran yang direkomendasikan penulis adalah: (1) penelitian ini akan dapat dilkembangkan dan menjadi semikin sempurna jika ada variabel lain selain empat variabel dalam mendeteksi kondisi pasien rawat inap; (2) penilaian kondisi pasisen dengan mengunakan membership function dari sistem fuzzy harus terus dicari dan benar-benar disesuaikan dengan kondisi pasien, sehingga menghindari kesalahan yang disebabkan oleh kesalahpahaman terhadap pasien; (3) sistem diharapkan untuk terus di-update informasi kondisi pasien, dan jadwal dokter yang ditampilkan dalam sistem monitoring pasien ini; (4) disarankan untuk melakukan back-up data secara berkala untuk menghindari resiko yang tidak diinginkan.

\section{DAFTAR PUSTAKA}

Russell, Stuart dan Novig, Peter. (2003). Artificial Intelligence A Modern Approach ( $2^{\text {nd }}$ edition). New Jersey: Pearson Education. 